\section{Germination and seedling growth of holm oak (Quercus ilex L.): effects of provenance, temperature, and radicle pruning}

\author{
Servet Caliskan
}

This study tested acorn characteristics and the germination behavior of different provenances of Holm oak (Quercus ilex L.) and the effects of radicle clipping of germinated acorns on 1-0 year-old seedling morphology and their field performances. The results revealed that all acorn characteristics among different provenances were significant. Quercus ilex acorns germinated well at alternating temperatures of $20 / 10{ }^{\circ} \mathrm{C}$ compared to a constant $20{ }^{\circ} \mathrm{C}$ temperature. Radicle clipping of $Q$. ilex significantly increased the shoot height and root collar diameter. The average number of main roots resulting from radicle clipping was 2.8 times more than unclipped treatment. The results can contribute to nursery practices and artificial regeneration of this species.

Keywords: Holm Oak, Seed Germination, Radicle Pruning, Quercus ilex, Sowing, Artificial Regeneration

\section{Introduction}

The genus Quercus includes over 500 species worldwide (Oldfield \& Eastwood 2007) of which 18 are present in Turkey (Hedge \& Yaltirik 1982). Approximately 5.15 million ha of Turkish forests were covered by oak forests and more than half of this area (3.05 million ha) is degraded (Anonymous 2012). Quercus ilex (Holm oak), is an evergreen oak species that can be found both in shrub and tree forms (Yaltirik 1984), in pure or mixed stands, and is a typical Mediterranean sclerophyll species (Palacios et al. 2009). The holm oak is distributed primarily in three distinct areas: (i) north Africa from Tunisia to Morocco; (ii) on several large islands, e.g., Crete, Sicily, and Corsica; and (iii) in southern (continental) Europe, along a continuum from Turkey to Portugal (Michaud et al. 1995). In Turkey, Q. ilex occurs in western Black Sea coasts and in southwestern Anatolia mixed with other pseudomaquis and maquis species, respectively. Maquis is the dominant vegetation type growing in Mediterranean climate conditions (Boydak et al. 2006, Kaya \& Aladag 2009).

Heavy degradation of vegetation in large areas of the Mediterranean basin call for re-

habilitation with native coniferous and broadleaves species (Boydak et al. 2006). Mediterranean landscapes have been modified since long time by human activities. Fire, grazing pressure, shifting agriculture, and overcutting for fuel and other purposes are important degradation and/or selection factors in all the Mediterranean countries (Aschmann 1973, Naveh \& Dun 1973, Fox 1982, Naveh \& Lieberman 1984, Boydak \& Dogru 1997, Zagas et al. 1998, Vallejo et al. 2000, Boydak et al. 2006). Moreover, it is expected that climate change could make Mediterranean ecosystems even more vulnerable (Gorissen et al. 2004, Wessel et al. 2004, Gratani et al. 2012). A decrease in Mediterranean shrublands cover might accelerate soil degradation and erosion (Haase et al. 2000, Gratani et al. 2012). The Holm oak plays a vital role in soil and water conservation and its acorns are important nourishment for many wild and domestic animals (Shakesby et al. 2002, Plieninger et al. 2003, Linan et al. 2011). On the other hand, Quercus ilex is an element of maquis vegetation that can play an important role in the rehabilitation and restoration of the western and eastern Mediterranean countries. Holm oak

Department of Silviculture, Faculty of Forestry, Istanbul University, TR-34473, Bahcekoy, Istanbul (Turkey)

@ Servet Caliskan (servetc78@yahoo.com)

Received: Feb 05, 2013 - Accepted: Jul 31, 2013

Citation: Caliskan S, 2014. Germination and seedling growth of holm oak (Quercus ilex L.): effects of provenance, temperature, and radicle pruning. iForest 7: 103-109 [online 201312-18] URL: http://www.sisef.it/iforest/contents/?id=ifor0967-007

Communicated by: Giustino Tonon gains more interest for Mediterranean forestry, along with other evergreen species such as Quercus suber, Ceratonia siliqua, and Olea europaea, especially in restoration and reforestation activities (Galvàn et al. 2012). Similarly, Holm oak plays an important role in reforestation programs in Spain (Pausas et al. 2004, Galvàn et al. 2012), and in restoration and rehabilitation programs of degraded maquis and forest areas in Turkey.

Successful restoration and rehabilitation in Mediterranean areas strongly depend on the quality of seeds and seedligs used. So far, the influence of oak species seedling quality on artificial regeneration performance has received little attention. Moreover, fibrous rooted seedlings are highly desirable for restoration and rehabilitation activities, especially in Mediterranean countries. Such seedlings may be produced by undercutting or transplanting, though this is generally expensive and time consuming (Calikoglu et al. 2007). However, it has been reported that pruning of the emerged radicle promotes the branching of the taproot in several oak species (Barden \& Bowersox 1989, McCreary 1996, Ertas 2002, Tilki \& Alptekin 2006, Devine et al. 2009). Bonner (1982) also stated that sowing pre-germinated acorns with damaged radicles resulted in multiple branched taproots in two southern red oak (Quercus falcata var. pagodaefolia and Quercus shumardii). Seedlings may benefit of branched multiple taproots in that root surface area becomes larger than that of seedlings with a single taproot (Devine et al. 2009).

A limited number of investigation have been carried out regarding Holm oak in maquis vegetation (Özalp 1993, Kaya \& Aladag 2009), and oak seed and seedling morphology in Turkey (Ertas 1996, Genc et al. 2000, Ertas 2002, Tilki \& Alptekin 2006). Information on morphological variation in seed characteristics among the natural populations of a species is useful for tree improvement programs in that survival, growth and biomass allocation performances of seedlings largely depend on seedling quality (Singh et al. 2010). The objectives of this study were to determine: (a) acorn characteristics and germination behavior of different provenances of Quercus ilex; and (b) the effects of radicle clipping of germinated acorns on 1-0 year Holm oak seedling morphology, in order to assess their future field performances in rehabilitation and planting programs.

\section{Material and methods}

Acorn collection and determination of morphometric characteristics

Acorns were collected from mature trees in Canakkale $\left(40^{\circ} 10^{\prime} \mathrm{N}, 25^{\circ} 50^{\prime} \mathrm{E}\right.$, elevation 


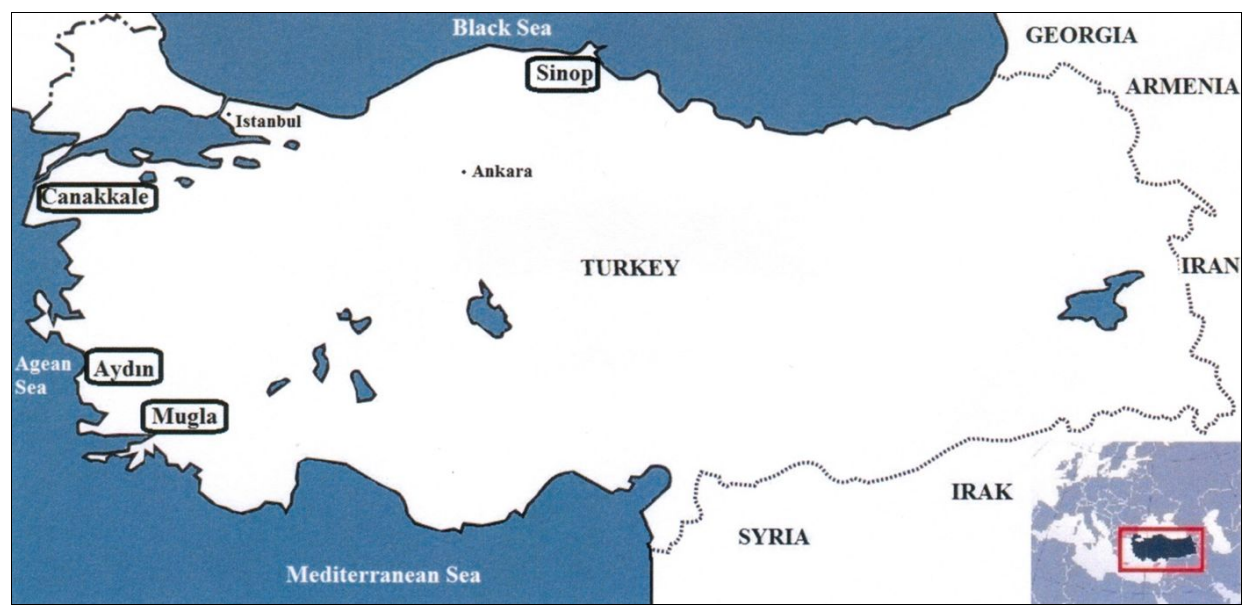

Fig. 1 - Map showing the locations of acorn collection sites.

$175 \mathrm{~m}$ a.s.l.), Sinop $\left(40^{\circ} 01^{\prime} \mathrm{N}, 35^{\circ} 00^{\prime} \mathrm{E}\right.$, 50 m a.s.1.), Aydin ( $37^{\circ} 39^{\prime}$ N, $27^{\circ} 05^{\prime}$ E, 10 $\mathrm{m}$ a.s.l.), and Mugla ( $36^{\circ} 43^{\prime} \mathrm{N}, 27^{\circ} 32^{\prime} \mathrm{E}$, $850 \mathrm{~m}$ a.s.1.- Fig. 1). The climate at all sites is a typical maritime climate. The annual mean precipitation and annual mean temperature are respectively: $521 \mathrm{~mm}$ and $14{ }^{\circ} \mathrm{C}$ in Sinop; $513 \mathrm{~mm}$ and $15{ }^{\circ} \mathrm{C}$ in Canakkale; 525 $\mathrm{mm}$ and $18^{\circ} \mathrm{C}$ in Aydin; and $979 \mathrm{~mm}$ and 15 ${ }^{\circ} \mathrm{C}$ in Mugla (Turkish State Meteorological Service 2013). Bedrocks in all sites are mainly limestone.

Collected acorns were placed in partially sealed plastic bags and transported to the laboratory. Acorns were floated in water to eliminate insect damaged or dead acorns. Sinking acorns were then selected if no damage was visible. Weight, length, and width were singly measured on 100 randomly drawn seeds from each provenance in five replications each of 20 seeds. The coefficient of variation $(\mathrm{CV})$ was determined based on the overall mean and total variance for each measured trait.

\section{Germination tests}

Germination tests were carried out on $18 \mathrm{x}$ $11 \times 4.5 \mathrm{~cm}$ trays in a germination chamber. Trays were filled with sieved sand, autoclaved at $121{ }^{\circ} \mathrm{C}$ for 20 minutes, and then acorns placed on moist sand. Tests were performed with five replicates of 20 acorns for each provenance. Trays were examined daily for 30 days following the first signs of germination. Seeds were considered germinated when radicles were more than $5 \mathrm{~mm}$ long and showing geotropism.
Germination tests were carried out at constant $\left(20 \pm 0.5^{\circ} \mathrm{C}\right)$ and alternating $(20 / 10 \pm$ $0.5^{\circ} \mathrm{C}$ ) temperatures. Germination data were expressed as germination percentage $(G P)$, peak value $(P V)$, and germination value $(G V)$. $G P$ is the percentage of seeds germinated at the end of the test. $P V$ is the highest number obtained dividing $G P$ by the number of days elapsed. $G V$ was calculated as follows (Djavanshir \& Pourbeik 1976 - eqn. 1):

$$
G V=\frac{\sum d G S}{N} \cdot \frac{N_{g s}}{100} \cdot 10
$$

where $G V$ is the germination value, $d G S$ is daily germination speed, $N$ is the frequency or the number of $d G S$ calculated during the test, $N_{\mathrm{gs}}$ is the number of germinated seeds, and 10 is a constant.

\section{Seedling growth and radicle pruning}

Pre-germinated acorns from Sinop and Mugla provenances were analysed for seedling morphology, and sowed in a forest nursery in Istanbul-Bahçeköy. The nursery is located $41^{\circ} 10^{\prime} \mathrm{N}, 28^{\circ} 59^{\prime} \mathrm{E}$, and elevation $116 \mathrm{~m}$ a.s.l. The climate at the nursery is a humid, mesothermal, and maritime climate with a moderate water deficit over summer months according to the Thornthwaite's classification method. Annual mean precipitation is around $1091 \mathrm{~mm}$, and mean annual temperature is $12.8{ }^{\circ} \mathrm{C}$. Most of the precipitation falls between October and March (Balci et al. 1986, Özhan et al. 2010, Akburak et al. 2013).

Acorns were divided into two different groups: radicles left intact and radicles pruned back to $0.5 \mathrm{~cm}$. Acorns were individually sown on seedbeds with five replicates of 12 acorns for each treatment. Survival percentage, shoot height, root collar diameter, number of main roots, total diameter of main roots, and total diameter of main roots / root collar diameter were determined in 1-0 year Holm oak seedlings.

\section{Data analysis}

Parameters related to germination, such as germination percentage, peak value, and germination value, were considered as dependent variables in the analysis of variance carried out. Germination percentages were transformed using arcsine square root transformation. Population, temperature, and replications were used as independent variables (predictors). ANOVA for the germination traits were based on the following model (Sokal \& Rohlf 1995 - eqn. 2):

$$
Y_{i j k l}=\mu+P_{i}+T_{j}+R_{k}+(P T)_{i j}+e_{i j k l}
$$

where $Y_{\mathrm{ijk}}$ is the observed value of $k$-th replication of the $j$-th temperature of the $i$-th population (provenance), $\mu$ is the overall mean, $P_{\mathrm{i}}$ the population effect, $T_{\mathrm{j}}$ the effect of temperature, $R_{\mathrm{k}}$ the effect of replication, and $e_{\mathrm{ijk}}$ is the error.

In the radicle pruning treatments, seedling traits such as survival, shoot height, root collar diameter, number of main roots, total diameter of main roots, and total diameter of main roots $(\mathrm{mm}) /$ root collar diameter $(\mathrm{mm})$ (dependent variables) were analyzed using treatments as independent variables. Survi-

Tab. 1 - Morphometric characteristics of Quercus ilex L. acorns. Means within each column followed by different letters are significantly different $(\mathrm{p}<0.01)$. (SE): standard error.

\begin{tabular}{llrrrrrrrr}
\hline \multirow{2}{*}{ Provenance } & \multicolumn{3}{c}{ Acorn width $(\mathbf{m m})$} & \multicolumn{3}{c}{ Acorn length (mm) } & \multicolumn{2}{c}{ Acorn weight (gr) } \\
\cline { 2 - 10 } & Mean & SE & Range & Mean & SE & Range & Mean & SE & Range \\
\hline Canakkale & $12.8^{\mathrm{a}}$ & 0.15 & $9.0-16.3$ & $28.84^{\mathrm{a}}$ & 0.38 & $17.6-34.7$ & $2.95^{\mathrm{a}}$ & 0.38 & $0.55-4.96$ \\
Sinop $_{\text {Aydin }}$ & $13.03^{\mathrm{b}}$ & 0.12 & $10.8-16.2$ & $24.41^{\mathrm{b}}$ & 0.22 & $19.0-30.9$ & $2.64^{\mathrm{b}}$ & 0.07 & $1.50-4.84$ \\
Mugla & $13.15^{\mathrm{b}}$ & 0.09 & $10.4-15.5$ & $28.81^{\mathrm{a}}$ & 0.34 & $13.1-35.6$ & $3.06^{\mathrm{a}}$ & 0.07 & $1.53-4.98$ \\
Over four provenances & $13.66^{\mathrm{b}}$ & 0.16 & $9.7-17.4$ & $26.06^{\mathrm{c}}$ & 0.37 & $14.2-33.9$ & $2.90^{\mathrm{a}}$ & 0.09 & $0.98-5.13$ \\
\hline
\end{tabular}


val percentages were transformed using arcsine square root transformation. ANOVA for the radicle pruning treatments were based on the following model (Sokal \& Rohlf 1995 eqn. 3 ):

$$
Y_{i j}=\mu+T_{i}+e_{i j}
$$

where $Y_{\mathrm{ij}}$ is the observation of $j$-th seedling of the $i$-th treatment, $\mu$ is the overall mean, $T_{\mathrm{i}}$ is the effect of treatment, and $e_{\mathrm{ij}}$ is the error.

Duncan's multiple range test was applied to determine statistically significant differences among subsets $(\alpha=0.05)$.

\section{Results}

Results from ANOVA applied on acorn characteristics of Quercus ilex showed that differences among provenances were significant for all the traits considered (Tab. 1). The maximum range of variation in acorn width, length, and weight was observed for Mugla, Aydin, and Canakkale provenances (9.7-17.4 mm, 13.1-35.6 mm, and 0.55-4.96 gr, respectively). Largest width, length, and weight were observed for acorns from Mugla, Canakkale, and Aydin provenances, respectively. According to the results of the Duncan's test on acorn width and weight (Tab. 1), Canakkale population is distinct from Sinop, Aydin, and Mugla provenances. As for acorn length, no significant differences were found in between Canakkale and Aydin, though they showed significant differences with both Sinop and Mugla. Maximum coefficient of variation $(\mathrm{CV})$ was observed in acorn weight for all provenances (Fig. 2). For acorn weight, the maximum CV was recorded in the Canakkale provenance $(34.8 \%)$ with a minimum of $23.2 \%$ in the Aydin provenance. For acorn width and acorn length, the maximum $\mathrm{CV}$ was observed in Mugla provenance $(11.8 \%$ and $14.3 \%$, respectively).

Results from ANOVA showed that $G P$, $G V$, and $P V$ were significantly different among provenances $(\mathrm{p}=0.0001)$. The effect of temperatures was significant only for $G V$ and $P V(\mathrm{p}=0.0108$ and $\mathrm{p}=0.00018$, respectively). Interaction between provenances and temperatures did not reveal any significant effect (Tab. 2).

Germination percentage, germination value and peak value were the highest in the Sinop provenance at both constant $\left(20 \pm 0.5^{\circ} \mathrm{C}\right)$ and alternating $\left(20 / 10 \pm 0.5^{\circ} \mathrm{C}\right)$ temperature regimes. Germination performances of $\mathrm{Ca}$ nakkale, Mugla, and Aydin provenances were higher at the alternating than at the constant temperature regime. Contrastingly, Sinop provenance acorns revealed better performances in terms of germination parameters at constant rather than alternating temperature regime (Tab. 3, Fig. 3, Fig. 4).

Germination percentage, germination value, and peak value at $20{ }^{\circ} \mathrm{C}$ and $20 / 10{ }^{\circ} \mathrm{C}$

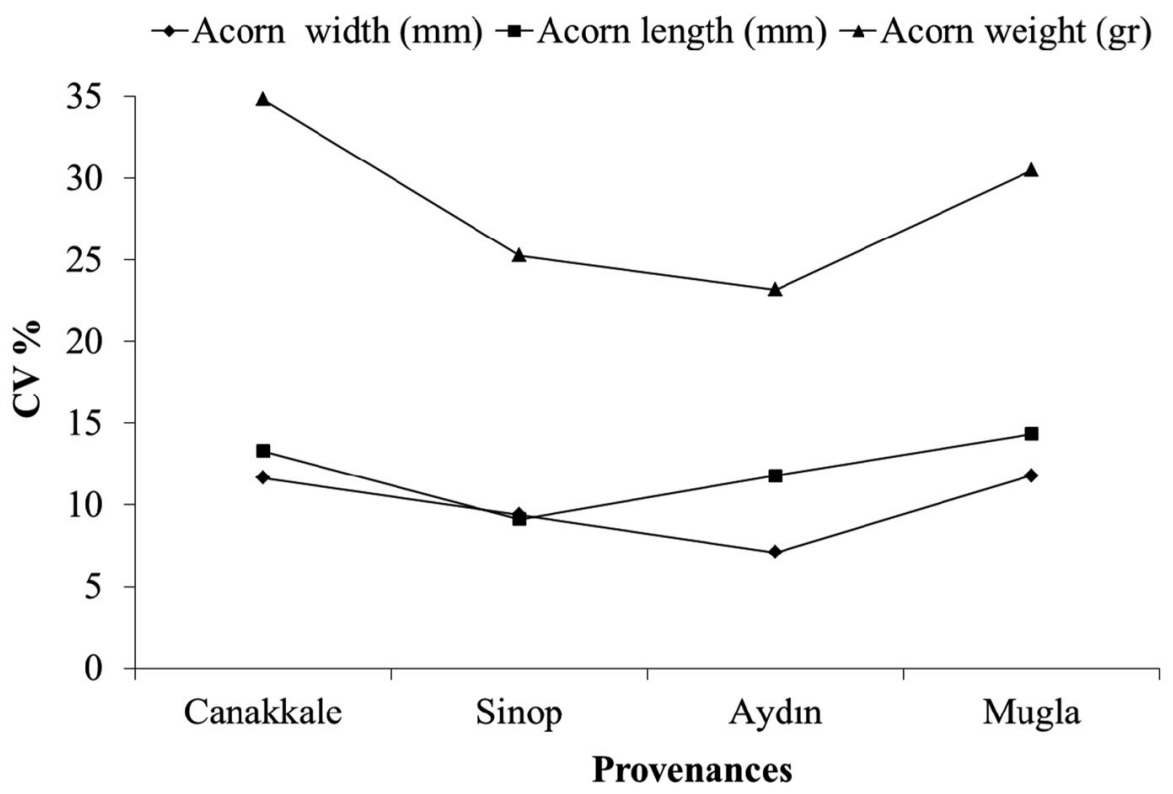

Fig. 2 - Coefficient of variation (CV) among different provenances for different acorn characters in Quercus ilex.

Tab. 2 - Results of the ANOVA carried out on germination percentage $(G P)$, germination value $(G V)$ and peak value $(P V)$ of the acorns of Quercus ilex.

\begin{tabular}{llccccc}
\hline \multirow{2}{*}{ Variable } & & \multicolumn{6}{c}{ Source of variation } \\
\cline { 2 - 7 } & Parameter & $\begin{array}{c}\text { Provenance } \\
(\mathbf{A})\end{array}$ & $\begin{array}{c}\text { Temperature } \\
(\mathbf{B})\end{array}$ & $\begin{array}{c}\text { Interaction } \\
(\mathbf{A ~ x ~ B )})\end{array}$ & Replications & Error \\
\cline { 2 - 7 } & $\mathrm{df}$ & 3 & 1 & 3 & 4 & 28 \\
\hline$G P$ & $\mathrm{MS}$ & 3610.635 & 180.625 & 119.375 & 102.292 & 121.518 \\
& $\mathrm{~F}$ & 29.71 & 1.49 & 0.98 & 0.84 & - \\
& P-value & 0.000 & 0.2329 & 0.4331 & 0.4825 & - \\
\hline$G V$ & MS & 2419.881 & 761.508 & 80.797 & 214.348 & 102.204 \\
& F & 23.68 & 7.45 & 0.79 & 2.10 & - \\
& P-value & 0.000 & 0.0108 & 0.5412 & 0.1232 & - \\
\hline$P V$ & MS & 51.287 & 22.695 & 1.048 & 3.933 & 1.910 \\
& F & 26.85 & 11.88 & 0.55 & 2.06 & - \\
& P-value & 0.000 & 0.000 & 0.7011 & 0.1283 & - \\
\hline
\end{tabular}

Tab. 3 - Germination of Quercus ilex L. acorns from four provenances at $20{ }^{\circ} \mathrm{C}$ and $20 / 10$ ${ }^{\circ} \mathrm{C}$. Means in the same column followed by different lowercase letter are significantly different $(\mathrm{p}<0.05)$; means in the same column followed by different uppercase letter are significantly different $(\mathrm{p}<0.05)$.

\begin{tabular}{cllcl}
\hline \multirow{2}{*}{$\begin{array}{c}\text { Temp. } \\
\text { Regime }\end{array}$} & Provenance & \multicolumn{3}{c}{ Germination Parameters } \\
\cline { 2 - 5 } constant & Canakkale & $\boldsymbol{G}$ & $\boldsymbol{G} \boldsymbol{P}$ & $2.1^{\mathrm{e}}$ \\
$\left(20^{\circ} \mathrm{C}\right)$ & Sinop & $30^{\mathrm{a}}$ & $5.0^{\mathrm{a}}$ & $8.7^{\mathrm{a}}$ \\
& Aydin & $81^{\mathrm{b}}$ & $49.0^{\mathrm{b}}$ & $6.2^{\mathrm{b}}$ \\
& Mugla & $70^{\mathrm{bc}}$ & $35.6^{\mathrm{c}}$ & $5.4^{\mathrm{b}}$ \\
& Mean & $60^{\mathrm{c}}$ & $27.2^{\mathrm{cd}}$ & $5.6^{\mathrm{A}}$ \\
\hline alternate & Canakkale & $60^{\mathrm{A}}$ & $29.2^{\mathrm{A}}$ & $2.3^{\mathrm{de}}$ \\
$\left(20 / 10^{\circ} \mathrm{C}\right)$ & Sinop & $41^{\mathrm{a}}$ & $6.6^{\mathrm{a}}$ & $5.6^{\mathrm{b}}$ \\
& Aydin & $77^{\mathrm{b}}$ & $29.4^{\mathrm{cd}}$ & $4.7^{\mathrm{cb}}$ \\
& Mugla & $73^{\mathrm{bc}}$ & $22.6^{\mathrm{cd}}$ & $3.9^{\mathrm{cd}}$ \\
& Mean & $68^{\mathrm{bc}}$ & $17.5^{\mathrm{d}}$ & $4.1^{\mathrm{B}}$ \\
\hline
\end{tabular}


Tab. 4 - Survival and seedling morphology from different radicle pruning treatments (average for two provenances). Means in the same row followed by different letters were significantly different $(\mathrm{p}<0.05)$.

\begin{tabular}{lcc}
\hline & \multicolumn{2}{c}{ Sowing Treatments } \\
\cline { 2 - 3 } Parameters & $\begin{array}{c}\text { Radicle not } \\
\text { clipped }\end{array}$ & $\begin{array}{c}\text { Radicle } \\
\text { clipped }\end{array}$ \\
\hline Survival (\%) & $66^{\mathrm{a}}$ & $62^{\mathrm{a}}$ \\
Shoot height (mm) & $147^{\mathrm{a}}$ & $169^{\mathrm{b}}$ \\
Root Collar Diameter (mm) & $3.5^{\mathrm{a}}$ & $3.8^{\mathrm{b}}$ \\
Number of the main roots & $1^{\mathrm{a}}$ & $2.8^{\mathrm{b}}$ \\
Total diameter of the main roots $(\mathrm{mm})$ & $3.5^{\mathrm{a}}$ & $7.1^{\mathrm{b}}$ \\
Total diameter of the main roots $(\mathrm{mm}) /$ & $1^{\mathrm{a}}$ & $1.9^{\mathrm{b}}$ \\
$\quad$ Root Collar Diameter $(\mathrm{mm})$ & & \\
\hline
\end{tabular}

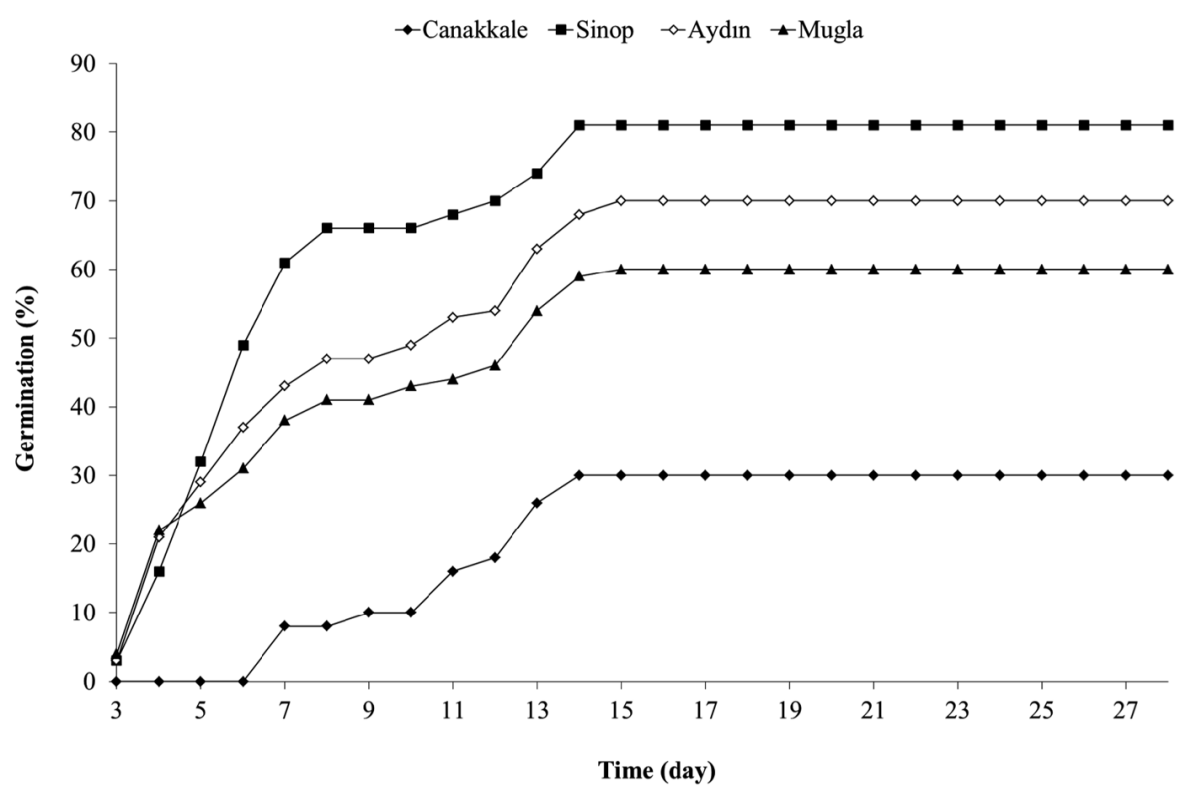

Fig. 3 - Germination of Quercus ilex acorns at the constant $\left(20 \pm 0.5{ }^{\circ} \mathrm{C}\right)$ temperature regimes.

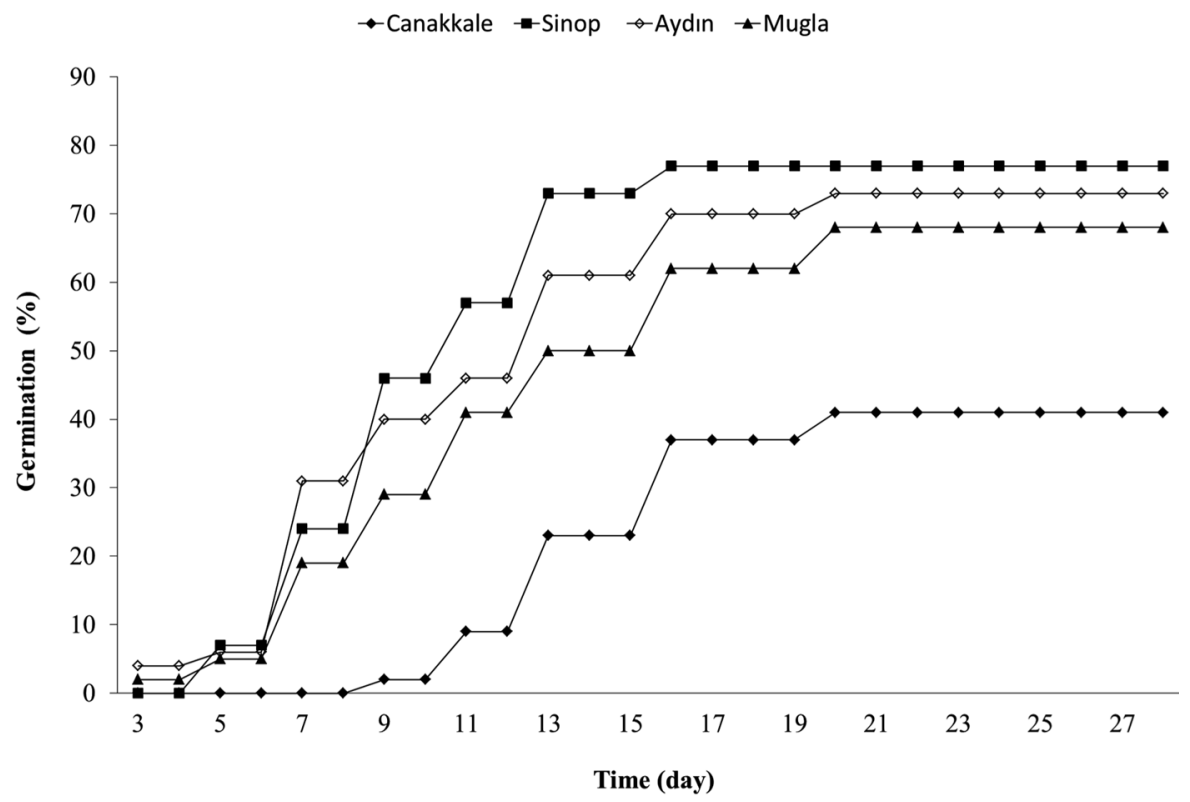

Fig. 4 - Germination of Quercus ilex acorns at alternating $\left(20 / 10 \pm 0.5^{\circ} \mathrm{C}\right)$ temperature regimes. were the highest in the Sinop provenance with lowest seed weight, and the lowest in the Canakkale provenance with medium seed weight (Tab. 1 and Tab. 3).

The effects of radicle pruning of germinated acorns on 1-0 year Holm oak seedling morphology were tested. Significant differences were found in shoot height, root collar diameter, number of main roots, and total diameter of main roots/root collar diameter. On the other hand, no significant differences were observed in survival. Finally, all the seedlings from the unpruned radicle treatment had single roots, while multiple roots were observed for all seedlings from the pruned radicle treatment (Tab. 4). Overall, seedlings with radicle pruned at germination seemed to perform better than unpruned seedlings (Tab. 4).

\section{Discussion}

Most Mediterranean sclerophyllous species develop morphological and physiological adaptations to the long and dry summer period, such as small and thick leaves, dense pubescence, deep water extraction system, and high water use efficiencies (Ozturk et al. 2010). In fact, drought stress is responsible for growth and survival of evergreen woody species in the Mediterranean basin (Gratani \& Varone 2004).

Local adaptations to specific ecological conditions may lead to differences among provenances in growth performances (Crescente et al. 2002, Ducousso et al. 1996). Population variability with respect to acorn morphology have been reported for Quercus ilex (Galvàn et al. 2012), Q. glauca (Singh et al. 2010), and $Q$. suber (Ramírez-Valiente et al. 2009). In a study on thirteen populations of holm oak throughout Spain (Galvàn et al. 2012), differences in acorn morphology between eastern and western provenances were reported, the latter showing also larger overall variation. The authors reported acorn weight ranging from 2.4 to $6.1 \mathrm{~g}(\mathrm{CV}=22$ $37 \%$ ), length ranging from 40.4 to $22.8 \mathrm{~mm}$ $(\mathrm{CV}=3-17 \%)$, and diameter ranging from 17.1 to $12.4 \mathrm{~mm}(\mathrm{CV}=13-35 \%$ - Galvàn et al. 2012). In the present study, ranges for acorn weight, length and width were 2.6-3.1 gr, 24.4-28.8 mm, $12.8-13.7 \mathrm{~mm}$, respectively. On the other hand, $\mathrm{CV}$ ranges for weight, length, and width were $23-35 \%$, 9$14 \%$, and $9-12 \%$, respectively. Moreover, significant differences among provenances were found for all the seed traits considered in this study. Afzal-Rafii et al. (1992) reported mean width values ranging from 12 to $13 \mathrm{~mm}$ for Holm oak acorns, while mean weight was 2.4-3 g, ranges similar to those observed in the present study $(12.8-13.7 \mathrm{~mm}$ and 2.6-3.1 g, respectively).

Gomez (2004) stated that large acorns of $Q$. ilex showed increased germination rate. In contrast, in the present study Canakkale 
provenance had the largest acorns but showed the lowest germination percentage, while Sinop provenance had the lightest acorns and the highest germination percentage. In some tree species, large seeds showed increased germination and survival (Ke \& Werger 1999, Cicek \& Tilki 2007). On the contrary, the rule larger seeds $=$ highest gerination rate does not hold for some other species, as it was in our study (Khera et al 2004, Tilki \& Alptekin 2005, Tilki 2010). However, it has been reported that acorn size and morphology are also affected by soil properties and stand characteristics (GeaIzquierdo et al. 2006).

In the present study, $Q$. ilex acorns showed better germination at alternating temperature regime $\left(20 / 10{ }^{\circ} \mathrm{C}-65 \%\right)$ than at constant regime $\left(20{ }^{\circ} \mathrm{C}-60 \%\right)$ temperature regime. However, similar differences among provenances in germination rate have been observed. Pasquini et al. (2011) reported for Holm oak germination percentages of two seed lots $(68 \%$ and $63 \%)$ very similar to those observed in the present study.

Radicle pruning has revealed a positive effect on seedling performances in this investigation, determining a larger taproot production and increasing height and root collar diameter of seedlings. Moreover, significant differences were found in shoot height, root collar diameter, number of the main roots, and total diameter of the main roots/root collar diameter of the two tested provenances, though no significant differences in seedlings' survival were observed at the end of the growing season. However, in Quercus vulcanica radicle clipping had no effect on survival, shoot height, and diameter of seedlings obtained from spring-sown acorns (Tilki \& Alptekin 2006). Radicle clipping had also no effect on shoot height and diameter of containerized $Q$. vulcanica 1-yearold seedlings from fall-sown acorns (Genc et al. 2000) and did not significantly alter height in Fagus orientalis (Calikoglu et al 2007). In the present study, the average number of main roots was 2.8 times higher for seedlings undergoing radicle clipping in comparison to unclipped treatment, while it was close to 2.5 times higher for radiclepruned seedlings of Quercus vulcanica after 8 months (Tilki \& Alptekin 2006). Radicle clipping resulted in more seedling branch roots both in Q.vulcanica (Genc et al. 2000) and Quercus douglasii (McCreary 1996), and in a greater terminal elongation in greenhouse conditions in northern red oak (Barden \& Bowersox 1989). Furthermore, radicle pruning prior to sowing did not adversely affect seedling production in two southern red oaks (Quercus shumardii and Quercus falcate var. pagodaefolia - Bonner 1982). Similar results were also obtained by Ertas (1996) in Quercus hartwissiana, where radicle pruning doubled the average number of taproots and increased the root collar diameters of the seedlings, and by Ertas (2002) in Quercus petraea, where root surface area and number of taproots increased in 1-0 year old radicle-pruned seedlings.

The present study confirmed the importance of radicle clipping of $Q$. ilex. Radicle clipping generally inhibits the development of main carrot-type tap root, and causes the formation of several tap roots and a more fibrous root systems. It is thought that such a root system may confer an advantage on seedlings, providing greater root surface area for the absorption of moisture and nutrients (Tilki \& Alptekin 2006). Radicle-pruning tecnhiques may be adopted in nursery in order to produce vigorous material to be used in reafforestation or rehabilitation activities in drought-prone or degraded areas frequently occuring in the Mediterranean basin. Moreover, it is well-known that height and root collar diameter of seedlings are among the major factors positively affecting planting success of broad leaved species. The slow growth and poor survival of planted oaks may be in part due to the root system (Barden \& Bowersox 1989). Finally, Tsakaldimi et al. (2005) highlighted that grading criteria for oak seedlings' shoot height and root-collar diameter are important parameters to be considered for successful reafforestation of sites with high environmental stress.

\section{Conclusion}

The aim of this study was to determine the acorn characteristics, germination behaviors, and effects of radicle clipping of different provenances of Holm oak (Quercus ilex L.) from northern and western regions of Turkey. Quercus ilex acorns better germinated at alternating temperatures rather than at the constant temperature regimes. Significant differences were detected among different provenances for all the measured seed traits. Pruning the radicle of germinated acorns before sowing has proven to positively affect 1-year-old seedlings of Quercus ilex, increasing their shoot height and root collar diameter.

\section{Acknowledgements}

I wish to thank Prof. Dr. C. Unal Alptekin for his support during the seed collection. I am grateful to Prof. Dr. Melih Boydak for his careful review of and useful comments on this manuscript. I sincerely thank Dr. Bilal Cetin for his support in the laboratory during the investigation.

\section{References}

Afzal-Rafii Z, Dodd RS, Pelleau Y (1992). Mediterranean evergreen oak diversity: morphological and chemical variation of acorns. Canadian Journal of Botany 70:1459-1466. - doi: 10.1139/ b92-184
Akburak S, Oral HV, Ozdemir E, Makineci E (2013). Temporal variations of biomass, carbon and nitrogen of roots under different tree species. Scandinavian Journal of Forest Research 28:816. - doi: 10.1080/02827581.2012.679680

Anonymous (2012). The state of Turkey's Forests. General Directorate of Forestry, Ministry of Water Affairs and Forestry, Ankara, Turkey. [in Turkish]

Aschmann H (1973). Man's impact on the several regions with Mediterranean climates. In: "Mediterranean type ecosystems, origin and structures" (Di Castri F, Mooney HA eds). Ecological Studies vol. 7, Springler-Verlag, Berlin, Heidelberg, New York, pp. 363-371.

Balci AN, Özyuvaci N, Özhan S (1986). Sediment and nutrient discharge through streamflow from two experimental watershed in natural oak-beech forest ecosytems near Istanbul, Turkey. Journal of Hydrology 85: 31-47. - doi: 10.1016/00221694(86)90075-2

Barden C, Bowersox TW (1989). The effect of root pruning treatments on red oak seedling root growth capacity. In: Proceedings of the "Central hardwood forest conference" (Rink G, Budelsky CA eds). Carbondale (Illinois - USA), 5-8 Mar 1989, no. 132, pp. 115-119.

Bonner FT (1982). The effect of damaged radicles of presprouted red oak acorns on seedling production. Tree Planter's notes 33: 13-15.

Boydak M, Dirik H, Calikoglu M (2006). Biology and silviculture of Turkish red pine (Pinus brutia Ten.). OGEM-VAK, Ankara, Turkey.

Boydak M, Dogru M (1997). The exchange of experience and state of the art in sustainable forest managements (SFM) by ecoregion: Mediterrenean Forests. XI. Dünya Ormancilik Kongresi Bildirileri 6: 165-185.

Calikoglu M, Caliskan S, Yilmaz M, Dirik H (2007). Effects of root clipping on some seedling characteristics of oriental beech (Fagus Orientalis Lipsky). Review of the Faculty of Forestry, Istanbul University 57:17-30. [online] URL: http://journals.istanbul.edu.tr/tr/index.php/ orman/article/viewFile/9668/8963

Cicek E, Tilki F (2007). Seed size effects on germination, survival and seedling growth of Castanea sativa Mill. Journal of Biological Sciences 7 (2): 438-441. - doi: 10.3923/jbs.2007.438.441

Crescente MF, Gratani L, Larcher W (2002). Shoot growth efficiency and production of Quercus ilex L. in different climates. Flora 197: 2-9. doi: 10.1078/0367-2530-00007

Devine DW, Harrington AC, Southworth D (2009). Improving root growth and morphology of containerized Oregon White Oak seedlings. The Tree Planters's Notes 53: 29-34.

Djavanshir K, Pourbeik H (1976). Germination value: a new formula. Silvae Genetica 25: 79-83. Ducousso A, Guyon JP, Krémer A (1996). Latitudinal and altitudinal variation of bud burst in western populations of sessile oak (Quercus petraea (Matt) Liebl.). Annals of Forest Science 53: 775-782. - doi: 10.1051/forest:19960253

Ertas A (1996). A study on silvicultural characteristics of Quercus hartwissiana. PhD Disserta- 
tion, Istanbul University, Istanbul, Turkey.

Ertas A (2002). Effect of radicle clipping on sessile oak (Quercus petraea Lieb.) seedling's root surface area and number of taproots. In: Proceedings of the Third Balkan Scientific Conference "Study, conservation and utilisation of forest resources". Sofia (Bulgaria) 2-6 Oct 2001, vol. 2, pp. 159-164.

Fox MD (1982). Vegetation changes in Mediterranean Australia since European settlement. In: Proceedings of the Symposium on "Dynamics and Management of Mediterranean-Type Ecosystems". San Diego (CA - USA) 22-26 June 1981. General Technical Report PSW-58, USDA Forest Service, pp. 112-117.

Galvàn VJ, Jorrín-Novo $\mathrm{J}$, Gómez $\mathrm{C}$, Ariza $\mathrm{D}$, García-Olmo J, Navarro-Cerrillo RM (2012). Population variability based on the morphometry and chemical composition of the acorn in Holm oak (Quercus ilex subsp. ballota [Desf.] Samp.). European Journal of forest Research. - doi: 10.1007/s10342-011-0563-8.

Gea-Izquierdo G, Canellas I, Montero G (2006). Acorn production in Spanish holm oak woodlands. Investacion Agraria - Sistemas y Recursos Forestales 15 (3): 339-354.

Genc M, Gulcu S, Bilir N (2000). Kasnak mesesi (Quercus vulcanica Boiss.) 'nde meyve tipiekim sekli-fidan morfolojisi etkilesimleri. [Interactions on fruit type-sowing style-seedling morphology of Quercus vulcanica Boiss.]. Orman Mühendisligi 8:21-24. [in Turkish]

Gomez JM (2004). Bigger is not always better: conflicting selective pressures on seed size in Quercus ilex. Evolution 58 (1): 71-80. - doi: 10.1111/j.0014-3820.2004.tb01574.x

Gorissen A, Tietema A, Joosten NN, Estiarte M, Peñuelas J, Sowerby A, Emmett BA, Beier C (2004). Climate change affects carbon allocation to the soil in shrublands. Ecosystems 7: 650-661. - doi: 10.1007/s10021-004-0218-4

Gratani L (2000). Leaf temperature effects on gasexchange in Quercus ilex L. growing under field conditions. Plant Biosystems 134: 19-24. - doi: 10.1080/11263500012331350295

Gratani L, Varone L (2004). Adaptive photosynthetic strategies of the Mediterranean maquis species according to their origin. Photosynthetica 42 (4): 551-558. - doi: 10.1007/S11099-005-00 $12-3$

Gratani L, Varone L, Ricotta C, Catoni R (2012). Mediterranean shrublands carbon sequestration: environmental and economic benefits. Mitigation and Adaptation Strategies for Global Change 18 (8): 1167-1182. - doi: 10.1007/s11 027-012-9415-1

Gunderson CA, Norby RJ, Wullschleger SD (1993). Foliar gas-exchange responses of two deciduous hardwoods during three years of growth in elevated $\mathrm{CO}_{2}$ : no loss of photosynthetic enhancement. Plant, Cell \& Environment 16: $797-$ 807. - doi: 10.1111/j.1365-3040.1993.tb00501.x Haase P, Pugnaire FI, Clark SC, Incoll LD (2000). Photosynthetic rate and canopy development in the drought deciduos shrub Anthyllis cytisoides L. Journal of Arid Environments 46: 79-91. - doi: 10.1006/jare.2000.0657

Hedge ICF, Yaltirik F (1982). Quercus L. In: "Flora of Turkey" (vol. 7). Eduinburgh University Press, Edinburgh, Scotland, UK, pp. 659683.

Kaya B, Aladag C (2009). Maki ve Garig Topluluklarinin Türkiye'deki Yayilis Alanlari ve Ekolojik Özelliklerinin Incelenmesi. [Distribution analysis in Turkey and ecologic characteristics of maquis and garriques communities]. Selçuk Üniversitesi Sosyal Bilimler Enstitüsü Dergisi 22: 67-80. [in Turkish]

Ke G, Werger MJA (1999). Different responses to shade of evergreen and deciduous oak seedlings and the effect of acorn size. Acta Oecologica 20 (6): 579-586. - doi: 10.1016/S1146-609X(99)00 $103-4$

Khera N, Saxena KA, Singh PR (2004). Seed size variability and its influence on germination and seedling growth of five multipurpose tree species. Seed Science and Technology 32:319-330.

Linan J, Cantos M, Troncoso J, Garcia LJ, Fernandez A, Troncoso A (2011). Some propagation methods for cloning holm oak (Quercus ilex L.) plants. Central European Journal of Biology 6 (3): 359-364. - doi: 10.2478/s11535-011-0007-y McCreary DD (1996). The effects of stock type and radicle pruning on blue oak morphology and field performance. Annals of Forest Science 53: 641-648. - doi: 10.1051/forest:19960242

Michaud H, Toumi L, Lumaret R, Li TX, Romane F, Di Giust F (1995). Effect of geographical discontinuity on genetic variation in Quercus ilex L. (holm oak). Evidence from enzyme polymorphism. Heredity 74: 590-606. - doi: 10.1038/ hdy. 1995.83

Naveh Z, Dun J (1973). The human degradation of Mediterranean lanscape in Israel. In: "Mediterranean type ecosystems, Origin and Structures" (Di Castri F, Mooney H A eds). Ecological Studies vol. 7, Springer-Verlag, Berlin, Heidelberg, New York, pp. 373-390.

Naveh Z, Lieberman AS (1984). Lanscape ecology, theory and application, Springer-Verlag New York, Berlin, Heidelberg, Tokyo.

Oldfield S, Eastwood A (2007). The red list of oaks. Fauna \& Flora International, Cambridge, UK.

Ozturk M, Dogan Y, Sakcali MS, Doulis A, Karam F (2010). Ecophysiological responses of some maquis (Ceratonia siliqua L., Olea oleaster Hoffm. \& Link, Pistacia lentiscus and Quercus coccifera L.) plant species to drought in the east Mediterranean ecosystem. Journal of Environmental Biology 31:233-245. [online] URL: http://www.ncbi.nlm.nih.gov/pubmed/20648838 Özalp G (1993). Datça (Resadiye) yarimadasinin bitki toplumlari [Plant communities of Datca (Resadiye) peninsula]. Review of the Faculty of Forestry, Istanbul University 43: 77-101. [in Turkish]

Özhan S, Gökbulak F, Serengil Y, Özcan M (2010). Evapotranspiration from a mixed deciduous Forest Ecosystem. Water Resources Management 24: 2353-2363 - doi: 10.1007/s11269009-9555-6
Palacios G, Cerrillo N M R, Campo A, Toral M (2009). Site preparation, stock quality and planting date effect on early establishment of Holm oak (Quercus ilex L.) seedlings. Ecological Engineering 35 (1): 38-46. - doi: 10.1016/j.ecoleng. 2008.09.006

Pasquini S, Braidot E, Petrussa E, Vianello A (2011). Effect of different storage conditions in recalcitrant seeds of holm oak (Quercus ilex L.) during germination. Seed Science and Technology 39: 165-177.

Pausas J, Blade'1 C, Valdecantos A, Seva J, Fuentes D, Alloza J, Vilagrosa A, Bautista S, Cortina J, Vallejo R (2004). Pines and oaks in the restoration of Mediterranean landscapes of Spain: New perspectives for an old practice-a review. Plant Ecology 171: 209-220 - doi: 10.10 23/B:VEGE.0000029381.63336.20

Plieninger T, Pulido JF, Konold W (2003). Effects of land-use history on size structure of holm oak stands in Spanish dehesas: implications for conservation and restoration. Environmental Conservation 30 (1): 61-70. - doi: 10.1017/S037689290 3000055

Ramírez-Valiente JA, Valladares F, Gil L, Aranda I (2009). Population differences in juvenile survival under increasing drought are mediated by seed size in cork oak (Quercus suber L.). Forest Ecology and Management 257: 1676-1683. doi: 10.1016/j.foreco.2009.01.024

Shakesby AR, Coelho AOC, Schnabel S, Keizer JJ, Clarke AM, Contador LFJ, Walsh DPR, Ferreira DJA, Doerr HS (2002). A ranking methodology for assessing relative erosion risk and its application to dehesas and montados in Spain and Portugal. Land Degradation and Development 13: $129-140$ - doi: 10.1002/ldr.488

Singh B, Prakash SK, Bhatt BP (2010). Provenance variation in seed and seedlings attributes of Quercus glauca Thunb in Garhwal Himalaya. India Indian Dendrobiums 63:59-63.

Sokal RR, Rohlf FJ (1995). Biometry ( $3^{\text {rd }}$ edn). WH Freeman \& Co., New York, USA.

Tilki F (2010). Influence of acorn size and storage duration on moisture content, germination and survival of Quercus petraea (Mattuschaka). Journal of Environmental Biology 31: 325-328. [online] URL: http://www.ncbi.nlm.nih.gov/pub $\operatorname{med} / 21047006$

Tilki F, Alptekin CU (2005). Variation in acorn characteristics in provenances of Quercus aucheri Jaub. et Spach and provenance, temperature and storage effects on acorn germination. Seed Science and Technology 33:441-447.

Tilki F, Alptekin CU (2006). Germination and seedling growth of Quercus vulcanica: effects of stratification, desiccation, radicle pruning and season of sowing, New Forests 32: 243-251.

Tsakaldimi M, Zagas T, Tsitsoni T, Ganatsas P (2005). Root morphology, stem growth and field performance of seedlings of two Mediterranean everygreen oak species raised in different container types. Plant and Soil 278: 85-93. - doi: 10.1007/s11104-005-2580-1

Turkish State Meteorological Service (2013). Meteorological data. Web Site. [online] URL: 
http://www.mgm.gov.tr/index.aspx

Vallejo VR, Bautista S, Cortina J (2000). Restoration for soil protection after disturbances. In: "Life and the environment in the Mediterranean" (Trabaud L ed). WIT Press, Southampton, UK.

Wessel WW, Tietema A, Beier C, Emmett BA, Peñuelas J, Riis-Nielson T (2004). A qualitative ecosystem assessment for different shrublands in western Europe under impact of climate change. Ecosystems 7: 662-671. - doi: 10.1007/s10021004-0219-3

Yaltirik F (1984). Turkiye Meseleri - Teshis Klavuzu. [Oaks of Turkey - A guideline]. General Directorate of Forestry, Ministry of Agriculture, Forest and Village Affairs, Istanbul, Turkey. [in Turkish]
Zagas, Th, Hatzistathis A, Tsitsoni T, Gkanatsas P (1998). Degradation of Mediterrannean forest ecosystems and silvicultural measures for their restoration. In: "European environmental research" (Giannias A ed). Series in Economics, Business and the Environment, East-West vol. 1, Athens, Greece, pp. 53-60. 